\title{
Regularization of hydroelectric reservoir levels through hydro and solar energy complementarity
}

\author{
Regularização do nível dos reservatórios hidrelétricos através da complementaridade \\ hídrica e solar
}

Gabriela Leal de Mouriño $^{1}$, Arcilan Trevenzoli Assireu ${ }^{1}$ and Felipe Pimenta ${ }^{2}$

${ }^{1}$ Universidade Federal de Itajubá, Itajubá, MG, Brazil

${ }^{2}$ Universidade Federal de Santa Catarina, Florianópolis, SC, Brazil

E-mails: gabrielamourino@hotmail.com (GLM), assireu@gmail.com (ATA), felipepimenta@gmail.com (FP)

Received: December 01, 2015 - Revised: April 07, 2016 - Accepted: April 10, 2016

\begin{abstract}
Hydrological changes during prolonged droughts, as verified in the last two decades in Brazil, may reduce the level of hydroelectric reservoirs to the point that energy rationings become necessary. Such fluctuations, have been mainly complemented by thermo power, which is much more expensive and polluting. This work addresses the possibility of complementing the hydro system with solar energy. Daily-accumulated solar radiation from São Paulo, covering the period from 1961 to 2012, is used to evaluate the seasonal and interannual variability of solar power generation. The computed solar energy is applied in a hybrid solar-hydro model, where the turbine outflow is reduced accordingly to the solar power production, so that storage is improved in the long-term. The study region is Itumbiara reservoir in Brazil's Paraná hydrographic basin. Results suggest that this hybrid system should improve the reservoir ability to confront interannual climate variability.
\end{abstract}

Keywords: Hydrological changes; Energy complementarity; Hybrid model; Climate variability.

\section{RESUMO}

Mudanças hidrológicas durante secas prolongadas, conforme verificado nas últimas duas décadas no Brasil, podem reduzir o nível dos reservatórios ao ponto de tornar necessário o racionamento de energia. Tais flutuações têm sido complementadas principalmente por termelétricas, que são significativamente mais onerosas e poluentes. Este trabalho aborda a possibilidade de complementar o sistema hídrico com a energia solar. Para isto, foram utilizados dados diários de radiação solar medidos por uma estação meteorológica da cidade de São Paulo durante o período de 1961 a 2012. Os mesmos possibilitaram avaliar a variabilidade da energia solar nas escalas sazonal e interanual. A inserção da energia solar resultante foi aplicada a um modelo híbrido solar-hídrico, em que o fluxo de saída da turbina é reduzido em conformidade com a produção de energia solar. O armazenamento é assim alcançado em longo prazo. A região de estudo é o reservatório de Itumbiara, localizado na bacia hidrográfica do Rio Paraná, Brasil. Os resultados sugerem que este sistema híbrido deve melhorar a capacidade do reservatório para enfrentar a variabilidade climática interanual.

Palavras-chave: Mudanças hidrológicas; Complementaridade energética; Modelo híbrido; Variabilidade climática. 


\section{INTRODUCTION}

Brazil's energy generation is based mainly on hydroelectricity, which is considered a clean energy source. However, it makes the country's energy system vulnerable to climate variability. Several reservoirs have reached their lowest levels in the beginning of 2015 facing a severe water crisis. Itumbiara's reservoir, the largest in the Furnas System, reached less than $11 \%$ of its capacity during this period (ONS, 2015).

Several studies and government agencies highlight the need to change the basis of Brazilian's energy mix. According to the National Energy Plan 2030, the development of hydroelectric potential will hardly be able to follow the rising demand of national electric energy (EPE, 2007).

Therefore, alternative energy sources have been studied in order to achieve the technical and economic competitiveness necessary to its big scale implantation. Nowadays, solar, wind, biomass and small hydroelectric plants stand out among the renewable sources. However, some renewable energy systems still face obstacles such as the high production and installation costs.

The discussion and identification of the complementarity between different sources of energy date back from the 1970s due to the oil crisis. Currently, its use also occurs due to environmental issues. Kruangpradit and Tayati (1996) suggested the use of solar energy to supplement the existing hidroelectric plants in Ban Khun Pae, in northern Thailand. Beluco, Krenzinger and Souza (2003) and Beluco, Souza and Krenzinger (2013) investigated the deployment of a hybrid system that generates energy from solar and hydro complementarity in Rio Grande do Sul, Brazil. Dester et al. (2013) discussed the renewable sources integration in Brazilian's energy mix from their complementarity with the hydroelectric plants. Silva et al. (2015) studied the time complementarity between offshore wind power and hydroelectric plants in Brazil,

Following this trend, Pimenta and Assireu (2015) simulated a hybrid hydro-wind energy system applied to a hydroelectric reservoir. The results suggest that this system can minimize seasonal energy fluctuations from hydroelectric plants and reduce the risk of supply during periods of prolonged droughts. In regard to the maximum storage capacity, while the historical records reached $25 \%$ in 2011 , in the simulation of the hybrid system the wind complementarity enabled the maintenance of high storage levels between 1994 and 2011, reaching 87\% of the maximum level at the end of the same period.

Wind and hydro sources show a time complementarity that can be considered ideal in some regions. Likewise, periods of lower precipitation rates are frequently associated with higher solar radiation (less cloud cover) and vice versa.

Despite the wide availability of solar radiation and the high value that solar energy could add to the Brazilian energy system, the installed capacity is still marginal, $22 \mathrm{MW}$ or $0.02 \%$ of the country installed capacity. Solar energy has a promising future in tropical and sub-tropical urban areas for at least three reasons: the generation is close to the consuming center, solar panels are becoming more viable in terms of cost, and because of its complementarity to hydro power. The most critical occurrences of reservoirs' levels coincides with the periods of reduced cloud cover.

In this context, this paper aims to evaluate the contribution of solar energy from a hypothetical scenery in which the roof areas of São Paulo would be covered by solar panels. After considering the inclusion of solar generation to Itumbiara's production, the water saving was estimated according to the maintenance of the reservoir's levels.

Although this is a first approximation, the results of this study bring an unprecedented discussion about the conversion of solar energy into water savings for hydroelectric reservoirs, in a scenario where this natural resource is gaining more attention given to this crises faced in the last two decades.

This paper is structured in three subsequent sections. The Methodology presents the theoretical model and the database used. The Results are explored and discussed in the third section and the Conclusions provide a summary of the study.

\section{METHODOLOGY}

São Paulo has an area of $1,530 \mathrm{~km}^{2}$ and represents $5.5 \%$ of the electric energy consumption in Brazil, surpassing 29.4 TWh (SÃO PAULO, 2015). In order to estimate the roof area available for solar use in the city, the methodology of Lange (2012) was employed. Estimates are based on urban topology, which considers different average roof areas per kind of habitation. The use rate of roofs for photovoltaic generation was also taken into account. It considers, among other factors, the average inclination of roofs and their average position related to the sun. Due to the lack of references for Brazil, the numbers used were those determined by Wiginton, Nguyen and Pearce (2010), which are between 0.9 in Central Europe and 0.3 in New Zealand. The wide range of values found lead to two different scenarios: An optimistic one and a pessimistic one.

For this paper, the roof area values for each type of household proposed by Ghisi et al. (2006) were considered, and, after analyzing the situation in 12 Brazilian states, an average roof area of $85 \mathrm{~m}^{2}$ for houses $\left(\right.$ area $\left._{\text {house }}\right)$ and $15 \mathrm{~m}^{2}$ for apartments (area $a_{\text {apts }}$ ) was estimated. Thus, from the available data at IBGE demographic census (IBGE, 2010), which indicates the number of existing households from each type, it was possible to estimate the usable roof area in the city of São Paulo from the following equations.

$$
\begin{aligned}
& A_{\text {house }}=N^{o} \text { houses } \cdot \text { Roof_area } \text { house }_{\text {apts }} \\
& A_{\text {apts }}=N^{o} \text { apts } \text { Roof_area } \text { apts }_{\text {ats }} \\
& A_{\text {total }}=\left(A_{\text {house }}+A_{\text {apts }}\right) \cdot \text { Utilization_rate }
\end{aligned}
$$

Solar radiation and cloud cover data were provided by IAG USP meteorological station. The historical series contains data from 1961 to 2012. Solar radiation data consist of daily accumulated, in $\mathrm{MJ} / \mathrm{m}^{2}$. From hourly cloud clover data, the monthly average cloud clover was determined, and its behavior was compared to the monthly average radiation data.

The rainfall variation in São Paulo was studied from a historical series of the rainfall station located on USP's CTH University City, provided by the National Water Agency (ANA) by Hidroweb platform.

The analysis of the degree of complementarity between photovoltaic energy and hydropower was held from the methodology 
proposed by Beluco, Krenzinger and Souza (2003) and Beluco, Souza and Krenzinger (2013). From all forms of complementarity, temporal is the most important one for this study, and it is given by Equation 4. This index analyzed the time interval between the minimum and maximum energy availability of each source. $\mathrm{D}_{\mathrm{h}}$ is the day corresponding to the maximum water availability and $\mathrm{d}_{\mathrm{h}}$ is the day where the availability is minimum. Similarly, $\mathrm{D}_{\mathrm{s}}$ is the day corresponding to the maximum solar availability and $\mathrm{d}_{\mathrm{s}}^{\mathrm{s}}$ is the day corresponding to the minimum value.

$$
i_{t}=\frac{\left|d_{h}-d_{s}\right|}{\sqrt{\left|D_{h}-d_{h}\right|\left|D_{s}-d_{s}\right|}}
$$

The analysis of hydro availability was based on the study by Assireu, Pimenta and Souza (2011), which reported the water level of Itumbiara's reservoir with Julian days, as shown in Figure 1.

In order to make a better comparison with the water level data, the daily average solar radiation was determined only with the data for the common period between the two studies, which was from April 1993 to August 2008.

The equations proposed by Pimenta and Assireu (2015) were adapted to a solar-hydro hybrid system (Equation 5) in order to estimate the potential water savings by the photovoltaic generation.

$$
Q_{\text {solar }}=\frac{P_{\text {solar }}}{\eta \varepsilon^{h} \rho g h^{h}}
$$

where: Qsolar is flow rate of water saved by photovoltaic generation $\left.(\mathrm{mm} \mathrm{day})^{-1}\right)$; Psolar is the photovoltaic energy generated (Watts); $\eta(0.85)$ and $\varepsilon h(0.9)$ are the efficiencies of the generator and the turbine, repectively; $\varrho$ is the specific mass of the water $(998 \mathrm{~kg}$ $\left.\mathrm{m}^{-3}\right)$; $\mathrm{g}$ is the gravity acceleration $\left(9.81 \mathrm{~m} \mathrm{~s}^{-2}\right)$; hh is the average water level of the reservoir $(76 \mathrm{~m})$.

After calculating $\mathrm{Q}_{\text {solar }}$, with Itumbiara's reservoir data provided by Furnas Centrais Hidrelétricas S.A., it was possible to define the volume of water saved by the integration of solar energy and the water level variation.
A simplification of the hydrological model can be represented by Equation 6, which considers the reservoir's volume variation.

$$
\frac{d V}{d t}=Q_{\text {river }}+Q_{\text {prec }}-Q_{\text {evap }}-Q_{\text {hydro }}
$$

The terms of the equation are in $\mathrm{m}^{3} \mathrm{~s}^{-1}$ and stand for: Qriver is the flowrate tributary of the river that reaches the reservoir; Qevap is the evaporated water flow on the surface of the reservoir; Qprec is the rainfall contribution; Qhydro is the outflow (including the part that goes through the turbines and that is released by the spillway).

Considering that the volume of the reservoir can be represented by $V(t)=h(t) \cdot A_{r}$, where Ar is the superficial area $\left(\mathrm{m}^{3}\right)$ and $\mathrm{h}$ is the reservoir level $(\mathrm{m})$, Equation 6 takes the following form, in which $q=Q / A_{r}$ (expression in $\mathrm{mm} \mathrm{dia}^{-1}$ ).

$\frac{d h}{d t}=q_{\text {river }}+q_{\text {prec }}-q_{\text {evap }}-q_{\text {hydro }}$

Equation 7 was adapted to mean values in order to compare the water balance of the reservoir operating alone and in complementarity with the photovoltaics, as shown in Equation 8. Then, it was included the photovoltaic generation, set forth in Equation 9.

$\left(\overline{\frac{d h^{c}}{d t}}\right)=A \bar{q}_{r i v e r}+B \bar{q}_{p r e c}-C \bar{q}_{\text {evap }}-D \bar{q}_{\text {hydro }}$

$\left(\overline{\frac{d h^{h}}{d t}}\right)=\left(\overline{\frac{d h^{c}}{d t}}\right)+E \bar{q}_{\text {solar }}$

The superscript "c" refers to the classical system, which considers only the hydropower, while " $h$ " identifies the equations for the hybrid system. The index A, B, C and D are used to adjust the balance equation for Itumbiara and it were adopted the same values as proposed by the referred authors. The index $\mathrm{E}$ is the

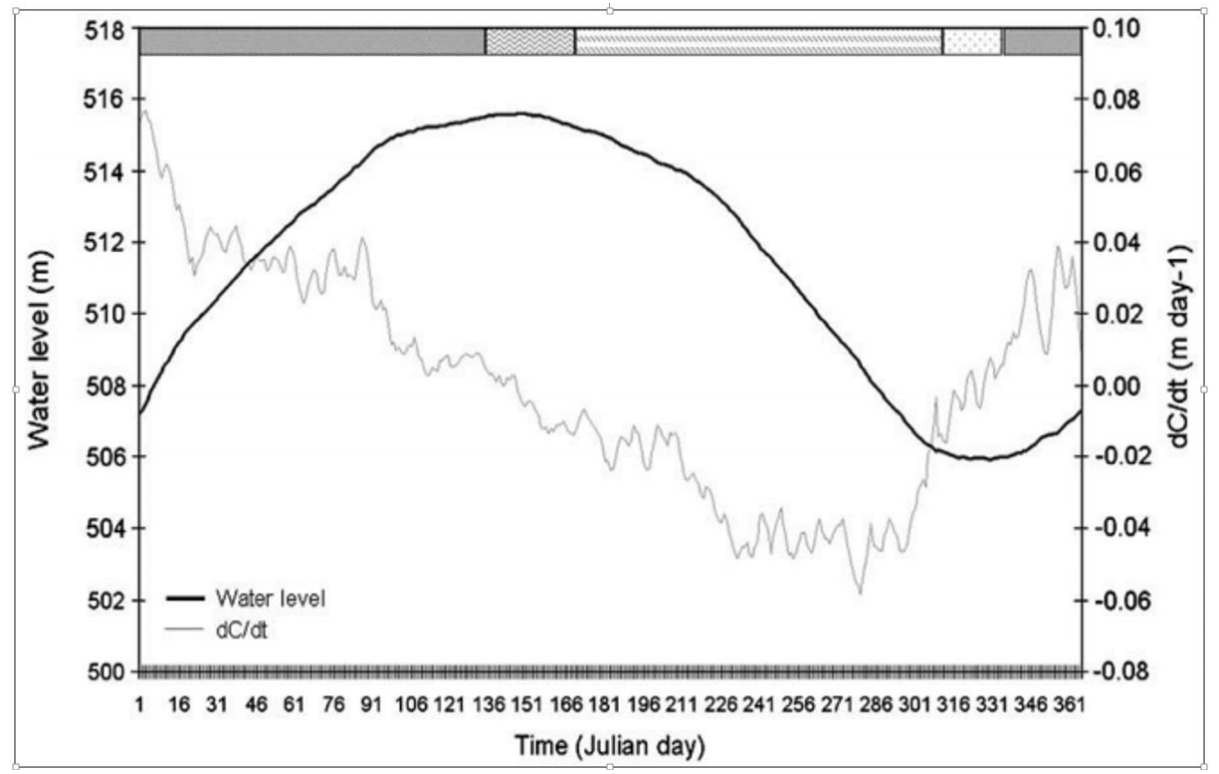

Figure 1. Average daily water level fluctuations (black line) and its derivatives in time (grey line). Source: Alcântara et al. (2010 apud ASSIREU; PIMENTA; SOUZA, 2011). 
utilization rate of roof area, which interferes in the photovoltaic generation and it is responsible for generating one result for the optimistic scenario and another one for the pessimist.

Thus, according to Pimenta and Assireu (2015), analyses of Itumbiara tributaries suggest that $\mathrm{A} \sim 1$, since the basin hydrographic area downstream from the river monitoring station is very small compared to the catchment area upstream. The outflow is well known, so $\mathrm{D}=1$. Surrounding relief suggests that the catchment area for local rainfall is $50 \%$ larger than the reservoir area, so $\mathrm{B} \sim 1.5$. The coefficient $\mathrm{C}$ was determined by minimizing the errors between the proposed equation and the observations, resulting in $\mathrm{C} \sim 0.5$.

It should be noted that these equations result in an average temporal condition for the system. Thus, the mean values proposed by the authors were used, according to which the indices, in $\mathrm{mm} \mathrm{day}{ }^{-1}$, are: $\mathrm{B} \bar{q}_{\text {prec }}=4.4 ; \mathrm{C} \bar{q}_{\text {evap }}=5.4 ; \bar{q}_{\text {river }}=146.1 ; \bar{q}_{\text {hydro }}=147.7$.

After the determination of the quantity of water saved in each scenario, an intermediate scenario was considered, in which it was possible to estimate the volume stored by the association of solar energy and hydropower from the data provided by Furnas Centrais Hidrelétricas S.A. The hydraulic power available after this association can be calculated by Equation 10 .

$$
P=\frac{g \cdot \rho \cdot \eta \cdot \varepsilon \cdot Q_{d} \cdot H_{L}}{1000}
$$

where: $\mathrm{P}$ is the electric power generated $(\mathrm{kW}) ; \eta$ is the turbine efficiency; HL is the net drop height (m); Qd is the output flow rate $\left(\mathrm{m}^{3} \mathrm{~s}^{-1}\right)$.

\section{RESULTS AND DISCUSSION}

\section{Temporal variability of solar radiation and cloud cover}

It is known that the nebulosity directly affects the amount of radiation that reaches photovoltaic panels, thus causing fluctuations in energy production. In order to investigate this relation, the behavior of the monthly average cloud cover was analyzed in comparison with the solar radiation data. The results are displayed in Figure 2.

Considering the results (Figure 2), there is an inverse relation between these two parameters: the higher the cloud cover, the lower the incidence of solar radiation at the surface. This happens because the clouds as well as the pollutants act as attenuators of radiation.
In regard to the average behavior of solar radiation, it is possible to notice two peaks, the first one between May and June and a higher one between September and October. The decrease in solar radiation between July and August can be harmful for the solar-hydro energy complementarity in a seasonal scale, as it coincides with the dry season.

\section{Complementarity index}

A preliminary evaluation of temporal complementarity between hydropower and photovoltaic energy in the study site was given by the comparison between precipitation and solar radiation data. It is noted that the precipitation shows great variations throughout the year, reaching its minimum values in August and peaks in January. The solar radiation behaves in a more constant way, reaching its maximum values in September and minimum in February (Figure 3).

Another comparison was made between the reservoir level and the variation of solar radiation throughout the year. For this analysis, daily average data of both energy sources were used, as shown in Figure 4.

The trend line in annual scale helps the visualization of the typical average behavior of solar radiation. It can be observed, in this case, that the minimum availability of radiation is closer to the maximum reservoir level and vice-versa.

This preliminary analysis confirms the possibility of temporal complementarity among solar and hydro energy, as the months of water deficit coincide with the higher availability of solar radiation and vice-versa. For greater certainty about this, the complementarity index, proposed by Beluco, Krenzinger and Souza (2003), was computed (Table 1).

Figure 5 shows the behavior of both solar and hydro average availability considering only the temporal complementarity between the two energy sources. This approximation does not take into account the amplitude variations generated by very distinct average values of availability.

As shown in Table 1, the gaps between maximum and minimum availability of water and solar radiation were, respectively, 153 and 148 days. In addition, the day that represents the minimum availability of one of the energy sources does not coincide with the day of maximum availability of the other. However, despite the fact that the complementarity is not perfect, there is a lag between the days of higher and lower availability of both sources, which justifies the analysis of potential water savings in Itumbiara's reservoir.

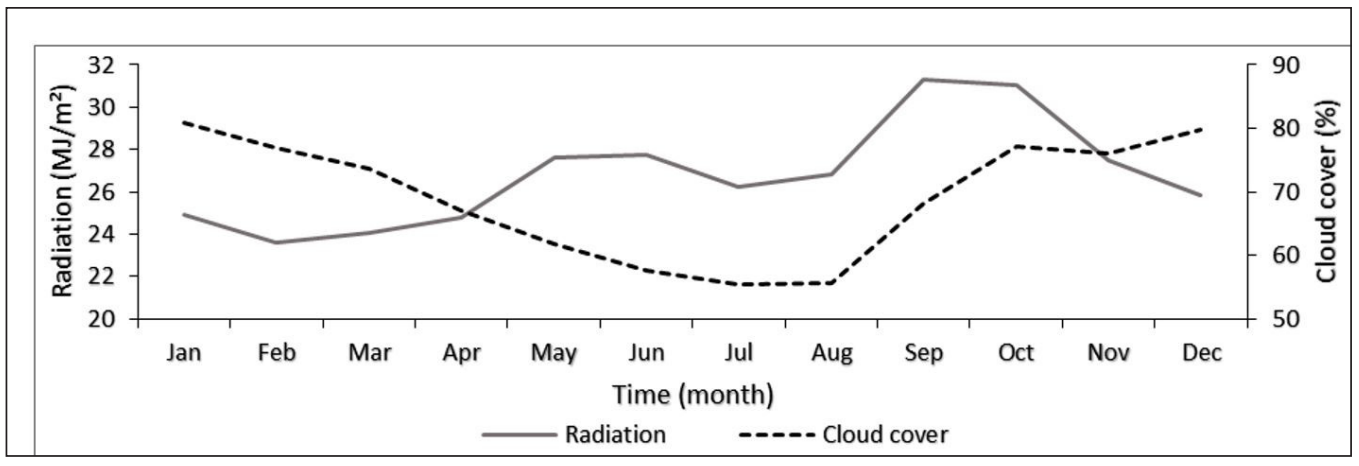

Figure 2. Ratio of the total cloud cover and incident solar radiation in São Paulo. 


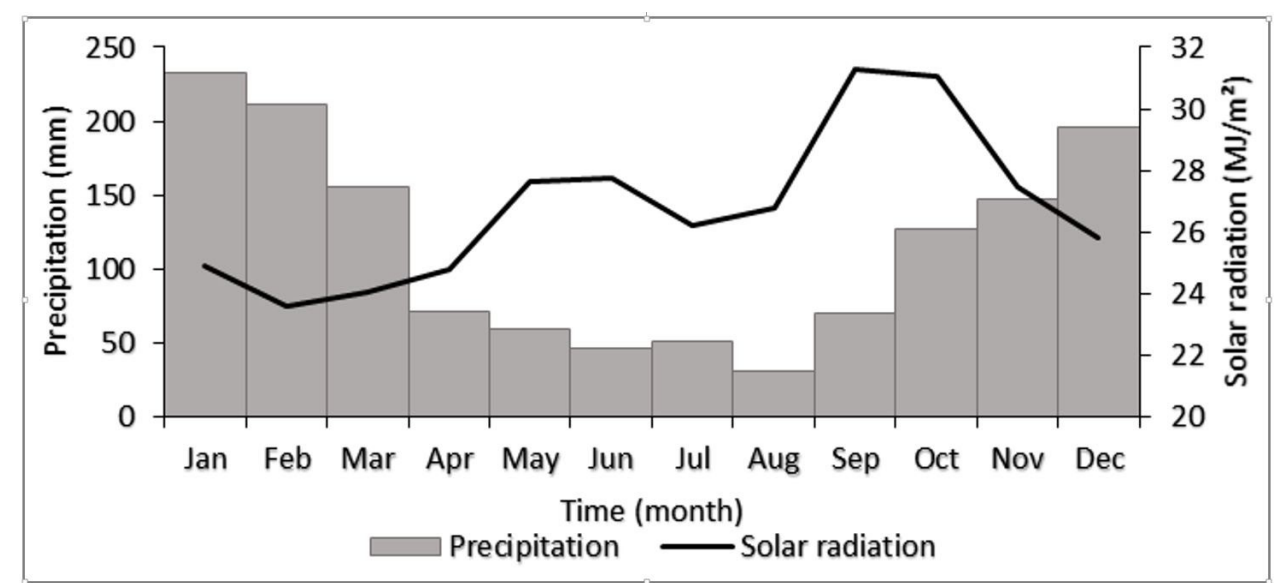

Figure 3. Average monthly rainfall data and monthly average insolation at the study site.

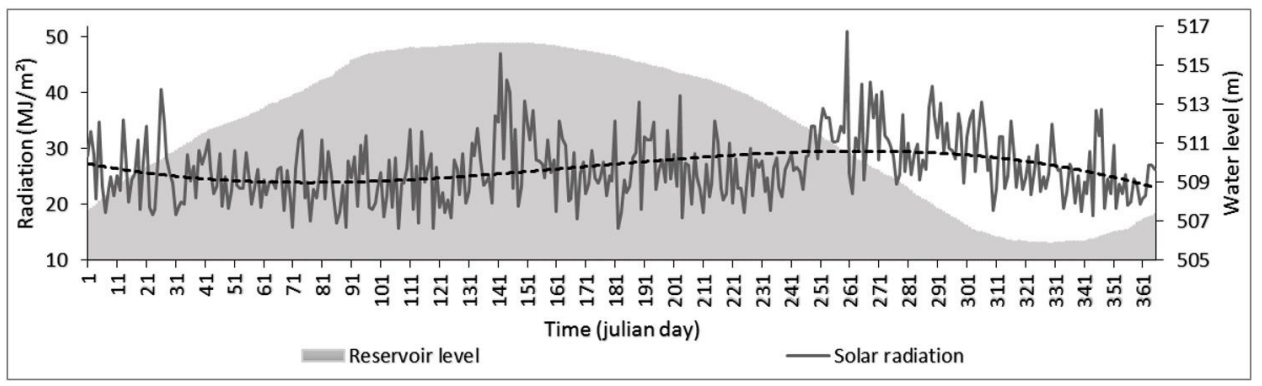

Figure 4. Comparison between the average behavior of the reservoir level and the incident solar radiation at the study site.

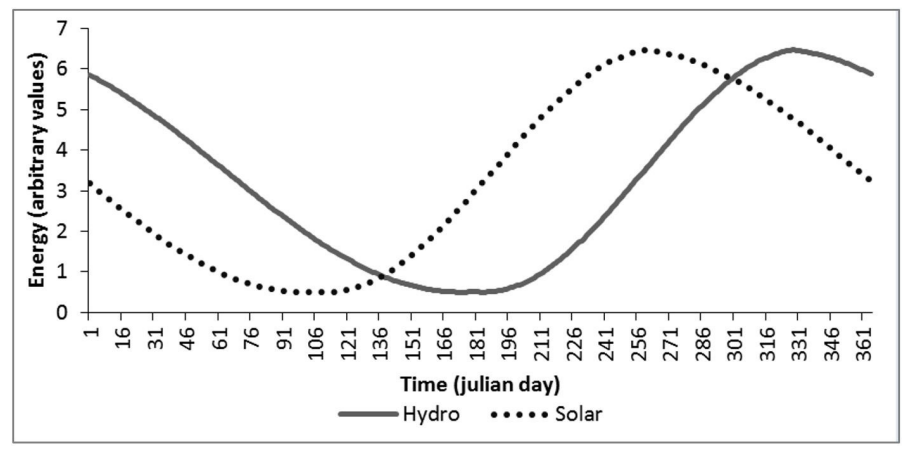

Figure 5. Maximum and minimum availability of solar and hydro energies over a year disregarding generation differences between the sources.

\section{Influence of photovoltaic generation at the level of Itumbiara's reservoir}

The photovoltaic energy generated $\left(\mathrm{P}_{\text {solar }}\right)$, as well as the decrease rate of the Itumbiara's reservoir level, vary depending on the usable roof area for such generation. Thus, considering the different utilization rates found in literature, the results shown in Table 2 were obtained.

Considering that the addition of photovoltaic energy to the grid directly implies a water economy of Itumbiara's reservoir, the Equations 5 to 9 were applied and the results are shown in Table 3.

In the pessimist scenario, in which photovoltaic generation is not considered, there is a decrease rate of the stored volume in
Table 1. Complementarity index in time [i].

\begin{tabular}{cc}
\hline $\mathbf{D}_{\mathrm{h}}$ & $\mathbf{1 8 0}$ \\
\hline $\mathbf{d}_{\mathrm{h}}$ & 328 \\
$\mathbf{D}_{\mathrm{s}}$ & 260 \\
$\mathbf{d}_{\mathrm{s}}$ & 107 \\
$\mathbf{i}_{\mathrm{t}}$ & 1.4686 \\
\hline
\end{tabular}

Table 2. Available roof area for photovoltaic use.

\begin{tabular}{lr}
\hline \multicolumn{1}{c}{$\mathbf{A}_{\text {total }}$ - Usable roof area $\left[\mathrm{km}^{2}\right]$} \\
\hline Pessimistic scenario & 67.5 \\
Optimistic scenario & 202.6 \\
\hline
\end{tabular}

Table 3. Water savings due to photovoltaic generation and rate of water level variation at Itumbiara's reservoir.

\begin{tabular}{cr}
\hline \multicolumn{2}{c}{$\mathbf{Q}_{\text {solar }}\left[\mathrm{mm} \mathrm{day}^{-1}\right]$} \\
\hline $\begin{array}{l}\text { Pessimistic scenario } \\
\text { Optimistic scenario }\end{array}$ & 3.514 \\
\hline \multicolumn{2}{c}{ Average hydro balance $\left[\mathrm{mm} \mathrm{day}^{-1}\right]$} \\
\hline$\overline{\left(d h^{c} / d t\right)}$ & -2.600 \\
$\left.\overline{\left(d h^{h} / d t\right.}\right)_{\text {pessimistic }}$ & 0.914 \\
$\overline{\left(d h^{h} / d t\right)_{\text {optimistic }}}$ & 7.943 \\
\hline
\end{tabular}


the reservoir of $-2.6 \mathrm{~mm} \mathrm{day}^{-1}$. When the photovoltaic generation expected for any scenario is added, there is an increase in this value, which becomes positive. Thus, the interconnection of Itumbiara with solar energy leads to water accumulation in the reservoir. In the optimistic scenario, the accumulation rate is evidently higher than the one expected for the pessimist scenario, since it is contributing with a higher power of solar source.

It is known that evaporation represents a great source of losses of useful volume in reservoirs. Regarding Itumbiara, the average evaporation rate is $5.4 \mathrm{~mm} \mathrm{day}^{-1}$, corresponding to an annual volume of over $1.53 \times 10^{9} \mathrm{~m}^{3}$. The integration with photovoltaic generation in the pessimist scenario would be responsible for the economy of about $65 \%$ of the volume loss due evaporation, while the optimistic scenario would exceed this volume and still entail an additional storage of $1.46 \times 10^{9} \mathrm{~m}^{3}$.

Figure 6 shows the behavior of Itumbiara's reservoir level, in meters, during a period of 16 years. It is possible to state that the maximum water head is 85 meters, which was reached at certain periods. From the graph it is observed that the minimum height reached in dry seasons was 62 meters.

Assuming that the behavior presented in Figure 6 will remain regular for the next 10 years, it is noted that there is no prospect of normalization of the reservoir level if the negative anomaly of rainfall remains. Considering the existence of a real scenario in which the photovoltaic generation is an intermediation between the two proposed scenarios, being equal to the evaporation rate $\left(5.4 \mathrm{~mm} \mathrm{day}^{-1}\right)$, this value corresponds to an addition of $2.0 \mathrm{~m}_{\text {year }}{ }^{-1}$ to the reservoir level, representing $12.5 \%$ of the reservoir's useful volume. Thus, considering the water saved by the integration of the solar energy, it is inferred that the reservoir would reach its maximum operating level even if the rainfall deficit observed remained constant over the coming years, as noted from Figure 7.

It is known that 2014 was marked by an extreme water crisis, considerably reducing the reservoirs water levels in Brazil. Adopting the level of 63 meters in 2015 and considering the possibility of integration between solar energy and hydropower, in the real scenario the reservoir will reach its maximum level in 2026. This estimative considers the persistence of the drought observed over the past 16 years during this period.

From this scenario, the power as a function of the water level was calculated. As the only variable index was the height of the water head, the power behaves in a linear way, as shown in Figure 7.

A linear increase in power of 20.7 MW can be noticed for every 2 meters of water level saved in the reservoir. This power is equivalent to about $1 \%$ of the generation capacity. The power saved becomes remarkable when noted that this economy corresponds to the generation power of a small hydroelectric plant.

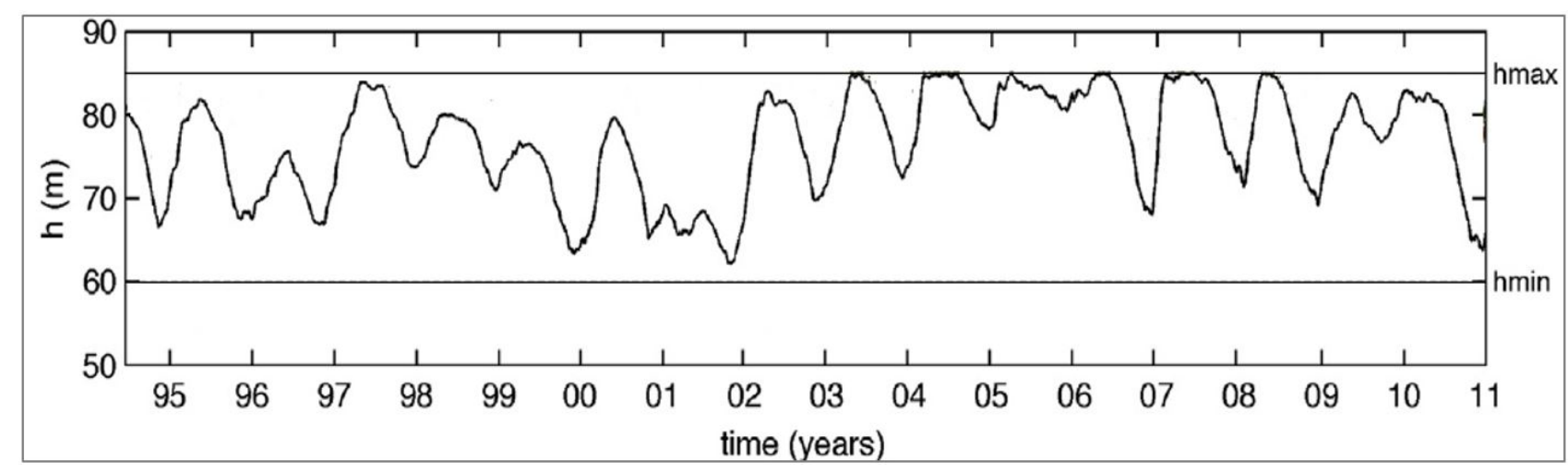

Figure 6. Itumbiara's water level over time. Source: Pimenta and Assireu (2015 - adapted).

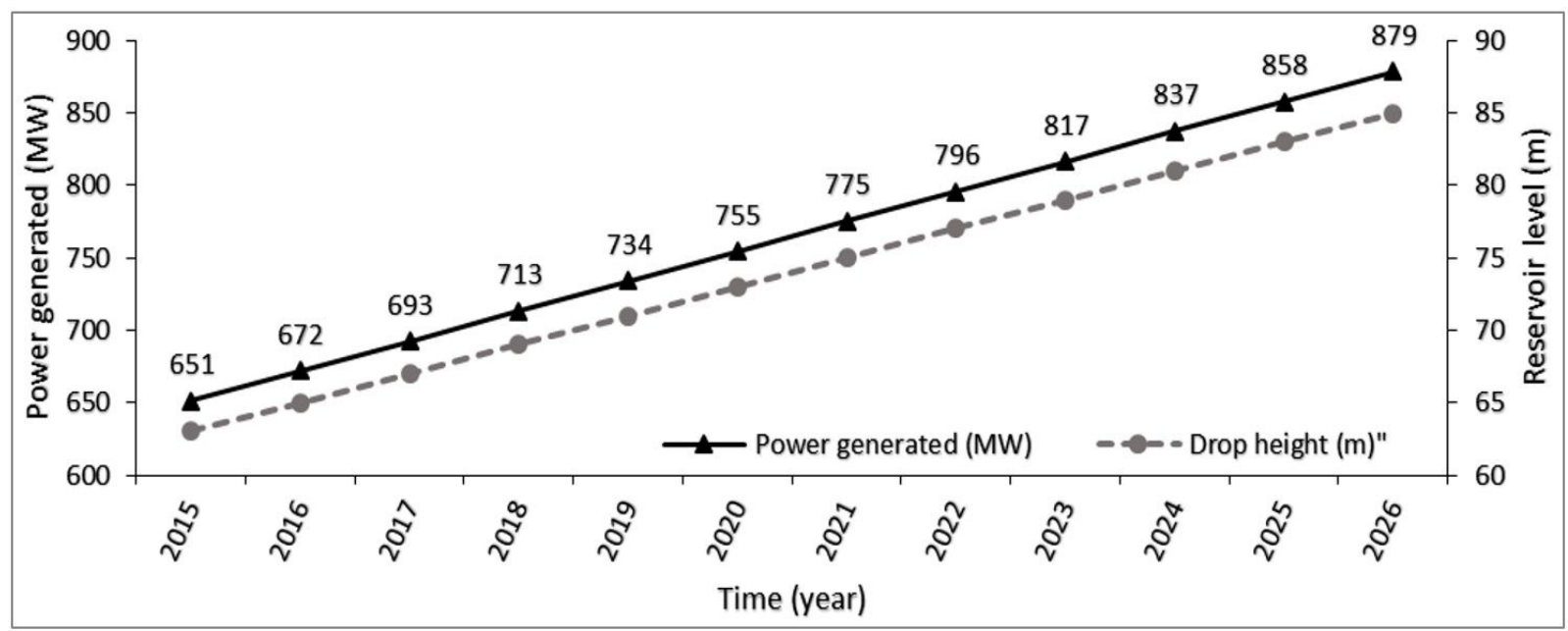

Figure 7. Relation between waterfall and generated power. 


\section{CONCLUSION}

Brazil's energy dependency on hydroelectric power plants makes the country vulnerable to climate variations. Given the increase in energy consumption and the water crisis observed in recent years, it is essential to develop alternatives that aim to diversify the energy mix. In this scenario, energy complementarity arises as a possibility that allows the integration of renewable sources of energy with the current generation system.

This work has its main focus on the temporal complementarity between photovoltaic and hydroelectric energies for the city of São Paulo. After analyzing the variation in solar radiation and water availability, the results showed that, despite the fact that the complementarity is not perfect, it is suitable for the development of a solar-hydro hybrid system. The maximum availability of one energy source is sufficiently close to the minimum availability of the other and vice versa.

The simulations for both optimistic and conservative scenarios showed the advantages of adopting the proposed system. Regarding the photovoltaic generation, it has shown great potential, surpassing hydroelectric generation in both cases. Its influence on Itumbiara reservoir was evident since it managed to overcome the losses due to evaporation in the optimistic scenario. The conservative scenario also showed a remarkable potential for water savings, reaching a value of $9.98 \times 10^{8} \mathrm{~m}^{3}$ year $^{-1}$.

In the hybrid system, the photovoltaic energy can be stored as hydraulic potential energy. A preliminary analysis showed that the association between the two sources of energy would be able to save up to the equivalent power produced by a small hydroelectric plant.

Thus, the simulation of the hybrid system demonstrated that the complementarity between solar and hydro energies could significantly benefit the maintenance of the reservoir levels, ensuring greater safety in hydro availability and in electricity distribution.

However, it is necessary to evaluate the economic viability of this enterprise, which will probably need governmental incentives.

\section{ACKNOWLEDGEMENTS}

IAG-USP and FURNAS Centrais Elétricas S.A. for makings the data set available for scientific research. FAPEMIG (Project APQ 00288/11; APQ 1575/14). CNPq (Projects 305123/2012-2 e 406801/2013-04).

\section{REFERENCES}

ASSIREU, A.; PIMENTA, F.; SOUZA, V. Assessment of the Wind power potential of hydroelectric reservoirs. In: ALCANTARA, E. H. Energy resources: development. Hauppauge: Nova Science Publishers, 2011. chap. 1.

BELUCO, A.; KRENZINGER, A.; SOUZA, P. A complementaridade no tempo entre as energias hidrelétrica e fotovoltaica. Revista Brasileira de Recursos Hídricos, v. 8, n. 1, p. 99-109, 2003. http:// dx.doi.org/10.21168/rbrh.v8n1.p99-109.

BELUCO, A.; SOUZA, P. K.; KRENZINGER, A. Influence of different degrees of complementarity of solar and hydro energy availability on the performance of hybrid hydro PV generating plants. Energy and Power Engineering, v. 5, n. 4, p. 332-342, 2013. http://dx.doi.org/10.4236/epe.2013.54034.

DESTER, M.; ANDRADE, M. T. O.; BAJAY, S. V. A integração das fontes renováveis na matriz de energia elétrica brasileira e o papel da hidroeletricidade como elemento facilitador da política energética e planejamento. Revista Brasileira de Energia, v. 19, n. 1, p. $127-168,2013$.

EPE-EMPRESA DE PESQUISA ENERGÉTICA. Plano nacional de energia 2030. Brasília, 2007.

GHISI, E.; MONTIBELLER, A.; SCHMIDT, R. W. Potential for potable water savings by using rainwater: na analysis over 62 cities in southern Brazil. Building and Environment, v. 41, n. 2, p. 204-210, 2006. http://dx.doi.org/10.1016/j.buildenv.2005.01.014.

IBGE - INSTITUTO BRASILEIRO DE GEOGRAFIA E ESTATÍSTICA. Censo demográfico 2010: São Paulo. Rio de Janeiro, 2010. Available from: <http://cidades.ibge.gov.br/xtras/perfil. php?codmun=355030> . Access on: 10 apr. 2015.

KRUANGPRADIT, P.; TAYATI, W. Hybrid renewable energy system development in Thailand. Renewable Energy, v. 8, n. 1, p. 514-517, 1996. http://dx.doi.org/10.1016/0960-1481(96)88910-5.

LANGE, W. J. Metodologia de mapeamento da área potencial de telhados de edificaçôes residenciais no Brasil para fins de aproveitamento energético fotovoltaico. Rio de Janeiro: TerraGIS, 2012.

ONS - OPERADOR NACIONAL DO SISTEMA ELÉTRICO. Volume útil dos principais reservatórios. [S.1.], 2015. Available from: $<$ http://www.ons.org.br/historico/percentual_volume_util.aspx $>$. Access on: 16 july 2015.

PIMENTA, F. M.; ASSIREU, A. T. Simulating reservoir storage for a wind-hydro hybrid system. Renewable Energy, v. 76, p. 757-767, 2015. http://dx.doi.org/10.1016/j.renene.2014.11.047.

SÃO PAULO. Secretaria de Energia. Eletricidade. São Paulo, 2015. Available from: <www.energia.sp.gov.br/portal.php/eletricidade>. Access on: 13 mar. 2015.

SILVA, S. S. F.; ALVES, A. C.; RAMALHO, Â. M. C.; LACERDA, C. D. S.; SOUSA, C. M. Complementaridade hidro eólica: desafios e perspectivas para o planejamento energético nacional. HOLOS, v. 6, p. 32-53, 2015. http://dx.doi.org/10.15628/holos.2015.2006.

WIGINTON, L. K.; NGUYEN, H. T.; PEARCE, J. M. Quantifying rooftop solar photovoltaic potencial for regional renewable energy policy. Computers, Environment and Urban Systems, v. 34, n. 4, p. 345-357, 2010. http://dx.doi.org/10.1016/j.compenvurbsys.2010.01.001.

\section{Authors contributions}

Gabriela Mouriño: Data processing and organization, analysis and preparation of the manuscript.

Arcilan Assireu: Analyses and final review of the manuscript.

Felipe Pimenta: Analyses and final review of the manuscript. 